\title{
CHALLENGES, IMPLICATIONS, AND INSPIRATIONS FOR PHILOSOPHY OF TIM INGOLD'S WAYFARING
}

\author{
A. Bastian N. LimAHEKIN*
}

\begin{abstract}
Tim Ingold is known in contemporary Anglophone social anthropology to be an original thinker who dares to think outside the mainstream of the discipline. His anthropological works are philosophically informed and heavily influenced by phenomenology. They account for and pay heed to "life," to the dynamism taking place in all the observed things, including non-living beings. Central to his anthropology of life is the notion of wayfaring. This article purports to introduce this notion and to explore the challenges, implications and inspirations it has for philosophy while taking a critical stand towards Ingold's account. It argues that the notion envisions citizens who have strong civic ties but at the same time can empathise with people of other countries. It argues furthermore that Ingold's critique of philosophy as embedded in such a notion can serve as an inspiration for doing philosophy in a more fruitful way, i.e., doing philosophy as wayfaring.

Keywords: Wayfaring, logic of inversion, meshwork, armchair approach, philosophy-as-a-wayfaring.
\end{abstract}

Abstrak: Tim Ingold dikenal sebagai seorang antropolog sosial Anglofon kontemporer yang memiliki pemikiran orisinal dan berani berpikir di luar arus utama disiplin ilmunya. Karya-karya antropologisnya adalah karya yang melek filsafat and sangat dipengaruhi oleh fenomenologi. Karya-karya tersebut peka terhadap "kehidupan," terhadap dinamika yang berlangsung pada setiap hal yang diamati, termasuk keberadaan yang tidak hidup. Salah satu konsep penting dalam pemikiran antropologisnya adalah pengembaraan. Dalam artikel ini penulis bermaksud

* Antonius Bastian N. Limahekin, Advanced Research Masters Program, Institute of Philosophy, KU Leuven, Kardinaal Mercierplein 2-bus 3200, BE-3000 Leuven, Belgium.E-mail: bastianlimahekin@gmail.com. 
memperkenalkan konsep tersebut serta mengeksplorasi tantangan, implikasi, dan inspirasinya terhadap filsafat sambil mengritik beberapa klaim Ingold. Penulis berpendapat bahwa konsep tersebut menawarkan sebuah visi tentang warga negara yang memiliki identitas sipil dan ikatan antarwarga yang kuat, namun pada saat yang sama memiliki empati terhadap warga negeri lain. Selain itu, penulis melihat kritik yang dilancarkan Ingold terhadap filsafat sebagai sebuah inspirasi dan undangan untuk mencari jalan menuju sebuah cara berfilsafat yang lebih merunduk ke bumi dan berbela rasa: berfilsafat sebagai sebuah pengembaraan bersama dengan yang-lain dan penuh empati terhadap yanglain.

Kata-kata Kunci: Kembara, logika inversi, rajutan-jejaring-relasibersimpul-terbuka, pendekatan belakang-meja, filsafat-sebagaikembara

\section{INTRODUCTION}

A social anthropologist by training, Tim Ingold is known for a bulk of works that revolve around "life." ${ }^{11}$ His "anthropology of life" attracts attention not only from those inside anthropology academia but also from those outside. It is philosophically interesting for two reasons. For one, it emphasises the dynamic life of things by way of an exposition saturated with concreteness. This phenomenological tone of his account can easily lead philosophically informed readers to infer that he is doing philosophy rather than anthropology. For another, it levels a severe critique against philosophy for inculcating what then became the mainstream worldview of modern people and the mainstream view of science.

1 Tim Ingold was born in 1948. He received his BA in Social Anthropology and Ph.D from Cambridge University in 1970 and 1976 respectively. He was Editor of Man (the Journal of Royal Anthropological Institute) from 1990 to 1992, became Max Gluckman Professor of Social Anthropology at the University in Manchester in 1995, and was the President of the Anthropology and Archaeology Section of the British Association for the Advancement of Science in 1999. He moved to the University of Aberdeen in 1999 and has been taking up Chair of Social Anthropology there since then. His more detailed biography can be found at http://www.abdn.ac.uk/elphinstone/staff/ details.php?id=tim.ingold. 
This essay serves a twofold purpose. The first is to introduce wayfaring, a central notion in Ingold's anthropology of life. The second is to explore the challenges, implications and inspirations of this notion for philosophy and for the thinking of self-identity and citizenship. I will also make some critical comments as I move along in the undertaking. To take up these tasks, I will first present Ingold's notion of wayfaring and consider the utopian character of the notion. Then I will explore the implications and challenges of Ingold's wayfaring to the self-identity concept of citizenship before finally considering the challenges and inspirations of this notion for the mode of doing philosophy.

There are some methodological caveats before proceeding further. Wayfaring is ubiquitous in Being Alive: Essays on Movement, Knowledge and Description, (BA) the work in which Ingold displays his philosophy of life in a full-fledged way as part of his effort to bring life back to the discipline of anthropology. ${ }^{2}$ So central is this notion that the book can even be said to be an elaboration of it in different guises. A fair presentation of Ingold's notion of wayfaring can therefore be attained only if all the chapters of BA are given equal treatment. Unfortunately, covering all the chapters of the book with an equal depth is not possible due to the constraints of space and time.

The strategy I employ, therefore, is to pick Chapter 12 of BA as my main text. I choose this chapter as my entry point because it is one of the two chapters in which Ingold presents his notion of knowledge as wayfaring most explicitly and densely. ${ }^{3}$ My presentation of the notion is based mostly on my reading of this chapter. In order to make sense of the chapter and bring the notion of wayfaring to greater clarity, I will occasionally turn to other chapters of BA. When the textual cross-reference is not sufficient to bring the ideas to a better light, I will take the freedom

2 Tim Ingold, Being Alive: Essays on Movement, Knowledge and Description (London: Routledge, 2011); abbreviated hereafter as BA when used in the body of the article.

3 Another chapter is Chapter 13. This chapter is a further elaboration and articulation of Chapter 12. This being so, the two chapters are intimately related to each other. Unfortunately, the writer cannot present them together here. 
to speculate based on my own life experiences or my - in Ingold's termslines and stories.

\section{INGOLD'S NOTION OF WAYFARING}

Ingold sets his notion of wayfaring as a critique against the "official science." ${ }^{4}$ In his view, one of the incorrect understandings that official science incurs is the concept of space. He observes that people today frequently use the term "space" to describe the world they inhabit. Despite its frequent use, he states, "space" is the most abstract, empty and detached term among the terms of its kind, such as "environment," "land," "field," "country," "earth," and "landscape," just to mention a few. ${ }^{5}$ This abstraction is for him something to be lamented.

Ingold argues that this abstraction is a result of what he terms "the logic of inversion," i.e., an act of converting the "relations along which a being lives its life in the world into internal properties of which its life is but the outward expression." ${ }^{6}$ Life (being-in-the-world) is in fact rich in its individuality and dynamic in its activities. A being moves, adjusts itself to its surrounding and goes through inner and outer transformations some of which bare eyes and shallow awareness cannot capture. Treating life as a set of internal properties does not do justice to its richness and dynamism.

The inversion with regard to space leads further to inversions in three other domains of understanding, i.e., of place, of movement and of knowledge. ${ }^{7}$ How the logic of inversion has taken place in the three domains and how it has transformed our understanding of place, movement and knowledge are the main concerns of Ingold in Chapter 12 of BA. In what follows, we will attend to the content of this chapter to unravel Ingold's notion of wayfaring.

4 By "official science" Ingold means the understanding and practice of knowledge taken to be conventional and mainstream in science today (Tim Ingold, Being Alive, p. 155). In his view, it is a product of modernity, although its seeds were already sowed in the ancient time.

5 Tim Ingold, Being Alive, p. 145.

6 Tim Ingold, Being Alive, p. 71.

7 Tim Ingold, Being Alive, p. 145. 
We begin with the logic of inversion taking place in the commonly held understanding of place. Ingold notices that there exists a habit of counter-posing place and space. This can be seen in the commonly held notion that "places exist in space." 8 Places, as this commonly held notion has it, are the spheres of the concrete and the particular in which the real experience takes place while space is the realm of the abstract and general. Here, Ingold observes, there occurs spatial scaling: space is regarded as higher and places lower. Space is given a privilege over places.

Who is responsible for this scaling? The philosophers are the culprits -so Ingold accuses while pointing at the work of J.E. Malpas as an example. ${ }^{9}$ It is the philosophers who classify places from a smaller and lower level to the larger and higher one and then assign a higher status to a place in a higher level of the spatial scale. The philosophers' spatial categorisation, he maintains, is an enclosure. In this categorisation, life is regarded as contained within the structures of an already built environment; it is seen as an enclosed capsule. This, in his view, is a reductive and incorrect understanding of life because life is in fact a "continuous birth," a process rather than a substance. ${ }^{10}$

He goes on putting forward the modern concept of life and room as expressed in the joint term "living room" (English) or Lebensraum (German) as a case in which the logic of inversion is at work in the translation process. ${ }^{11}$ In vernacular English, the word "room" means an interior part of a building enclosed by walls, whereas "living" is a suite of common indoor activities that would be undertaken by the occupants of this particular room. The German concept of Lebensraum is entirely different from the English word "living room." Citing the work of Heidegger, he maintains that Lebensraum rather means the very process of inhabiting the earth, not the occupation of a world already built. As such, "life" in

8 Tim Ingold, Being Alive, p. 146.

9 Tim Ingold, Being Alive, p. 146.

10 Tim Ingold, Being Alive, pp. 149 \& 237.

11 For Ingold's more detailed account of the conceptual difference between Lebensraum and "living room." See Tim Ingold, Being Alive, pp. 146, 147. 
the Lebensraum is an activity in the open and "room" is an opening that affords scope for growth and movement.

The logic of inversion, Ingold continues, takes place when the German Raum is translated into English as "space." Though the German Raum is nowadays the accepted equivalent of the Anglo-American concept of space, their connotations differ greatly from each other. In English, "room" and "space" are quite distinct: room is conceived as a highly localised compartment within the boundless totality of space. Being translated as space, Raum contains both two contradictory connotations of openness and closure, of absolute space and confined room, a contradiction that did not exist in the ancient sense of the opening. He therefore concludes that a transition has been at play in the translation, i.e., a transition from the ancient sense of clearing or opening to the modern oxymoron of "space and place" through a trick of inversion by making use of the concept of room. The idea that places are situated in space is a product of this modern inversion.

Ingold rejects the idea that places are situated in space. This idea, he says, comes from an understanding of life as being lived in this place or that place, exclusively here or there. To provide an alternative to it, he proposes an understanding of life as a trajectory of movement from one place to another. In this understanding, life is lived not inside places but "through, around, to and from them, from and to places elsewhere."12 It is an embodied experience of perambulatory movement. The term that he uses to describe life as an experience of perambulatory movement is wayfaring. For him, life is a wayfaring and human beings are wayfarers. What are places then in this understanding of life? Places are the knots and threads from which wayfarers are tied together as they move along the lines of wayfaring. ${ }^{13}$ When different knots of different wayfarers meet and are tied together, they constitute a meshwork. ${ }^{14}$

12 Tim Ingold, Being Alive, p. 148.

13 Tim Ingold, Being Alive, p. 149.

14 Tim Ingold, Being Alive, p. 152. 
We move on to the logic of inversion taking place in the official understanding of movement. Ingold contends that the official understanding of movement is also a product of the modern logic of inversion. ${ }^{15}$ To make his point, he identifies two kinds of understanding of movement, citing the Inuit's understanding and that of the sailors of the Royal Navy as the examples. In the Inuit's view, movement is continuous and lineal along paths of travel. ${ }^{16}$ For them, a person becomes a line as soon as he moves. For the sailors of the Royal Navy, on the other hand, movement is lateral and dotted across a surface. They conceive the vessel as a moving dot upon the surface of the sea and locate its position by latitude and longitude. Ingold calls the Royal Navy sailor's way "transport" and the Inuit's way "wayfaring."

For Ingold, there is a big difference between transport and wayfaring. ${ }^{17}$ Transport is essentially destination-oriented. What matters to the traveller are the locations or stops, which he regards merely as stepping stones towards his destination. Figuratively put, these stops or locations are like dots connected by lines. Travel is conceived of merely as a point-to-point connection. The destination of the traveller is predetermined and seen as a site of occupation. In transport, moreover, the basic nature of the traveller is unaffected and his identity is unchanging. Encased within his body, his vessel moves, but he himself, metaphorically speaking, does not.

Wayfaring, in contrast, is a continuous movement and development along the line. In wayfaring, a wayfarer is always on the move. He is his movement, just like the line which is drawn continuously. ${ }^{18}$ He grows, develops and is renewed as he moves along the pathways. A wayfarer sees every moment and place as important and he pays attention to each of them even to the point of being mindful to the characteristics of each place and being able to experience the ambience of the journey. ${ }^{19} \mathrm{He}$

15 Tim Ingold, Being Alive, p. 147.

16 Tim Ingold, Being Alive, p. 149.

17 Tim Ingold, Being Alive, p. 150.

18 Tim Ingold, Being Alive, p. 150.

19 It is not by accident that Ingold uses the terms wayfaring and wayfarer. Oxford Advanced 
inhabits every place along the path of movement and lays his trails there. The travel enriches him and changes his identity. This applies not only to travel as a spatial movement (literal meaning) but also as a life journey (figurative meaning). ${ }^{20}$

How does the logic of inversion take place in the case of movement? The inversion takes several forms. ${ }^{21}$ It occurs when the continuity of travel is converted to dots of occupation. It also takes place when there occurs a shift from paying attention to all happenings along the travel to paying attention only to this thing or that thing. The logic of inversion is also at work when self-identity, which is essentially dynamic and open, is made static and regarded only as internal unchanging properties. To put it symbolically, the inversion is at work when a hand-made continuous line is converted to a dotted line. ${ }^{22}$

Learner's Dictionary defines "wayfarer" as "a person who travels from one place to another, usually on foot" [Albert S. Hornby, Oxford Advanced Learner's Dictionary (Oxford: Oxford University Press, 2010), p. 1682)]. The point Ingold wants to make by using the word, I believe, has to do with "on foot." It may be difficult to get into Ingold's shoes at this point because many people nowadays travel by cars, trains and planes, thanks to the advanced technology of transport. Nevertheless, the experience of an inhabitant of a village in a third world country might help explain the point Ingold makes when he uses the term wayfaring. Wayfaring is what one does when one travels from his village to the nearest town to visit his family. As there is no public transport, he has to travel on foot along a stony path for twenty kilometres with bare feet. He has to watch his step carefully and to decide which side of the path he has to take in order to prevent himself from stumbling. Sometimes he meets his relatives and friends along the way so that he has to pause for some time, chat with them for a couple of minutes, and share some stories and laughter before resuming. He arrives at his family's home in the late afternoon, tired but feeling enriched because of the encounters along the trip. This kind of experience is what I believe to be what Ingold has in mind when he describes wayfaring as a spatial movement.

20 Here, wayfaring has a metaphorical meaning, i.e., as the movement of the inner self. The works that also express wayfaring in this sense are Rembrandt's painting, The Return of the Prodigal Son (c. 1661-1669), and Henri J.M. Nouwen's book, The Return of the Prodigal Son: A Story of Homecoming (New York: Doubleday, 1994). Exploring these works in tandem may help to understand Ingold's figurative wayfaring.

21 See Tim Ingold, Being Alive, p. 151.

22 Placing the logic of inversion in the context of profit-driven mentality of the modern society, I believe, may help explaining how modernity has incurred the logic of inversion. One important feature of modern culture is - to use Marx's term - the spirit of capitalism ignited by the Industrial Revolution. The core values of this spirit are profit and efficiency. This spirit and its values, I believe, have also affected people's attitude towards travel and time. In this profit-driven society, travels frequently aim 
Now we turn to the logic of inversion taking place in the official understanding of knowledge. ${ }^{23}$ The logic of inversion in the production of knowledge is closely related to the understanding of movement and place. Drawing his main example from the scientific research on climate change in the Arctic tundra in the Russian North, Ingold points out two different modes of knowledge acquisition: one is represented by the scientists, another by the pilot of a helicopter.

The scientists view knowledge acquisition from the eyes of passengers or occupants, i.e., as a movement from one point to another. This occurs, first of all, in their viewing of the research field. For them, the field of research is "locations," i.e., fixedly located areas, in which one location is treated as isolated from its surroundings and contexts. These locations are marked in the map of a research plan as dots in a straight line. These scientists, says Ingold, treat and view the fixed locations as "transects," i.e., a chain of point-to-point connections. These locations are regarded as laterally integrated locations. The data as raw materials are collected in these sites. Fixated to the chosen sites, the scientists are only interested in the content of the sites. They do not bother about how they have come there and where the sites are located. What matters to them is only the 'what it is', the contents. The contexts of the sites are neglected. The contents of data are cut off from their contexts, an act that Ingold calls "distillation." 24 These materials are then juxtaposed, compared and classified so as to form — through abstraction - a theory which is regarded as universal and independent of their contexts. Ingold calls the whole process of classification "compartmentalisation." ${ }^{25}$ Thus, the production

at transporting raw materials, products and people from one place to another. A desire for profit requires that travel or transport be made as fast as possible and time be compressed as much as possible. Life is thus lived in the fast lane such that people move from place to place without much time to reflect on the meanings of places, of encounters and of life, except probably in travels during holidays. What matters most is to get to the destination as fast as possible and to get the target accomplished.

23 Ingold's treatment of this issue can be found in Tim Ingold, Being Alive, pp. 153-155.

24 Tim Ingold, Being Alive, p. 155.

25 Tim Ingold, Being Alive, p. 155. 
of knowledge involves two kinds of integration: laterally integrated geography of locations and vertically integrated classifications of things found in locations. ${ }^{26}$

How about the knowledge acquired by the pilot? It is starkly different from the acquisition of knowledge by the mainstream scientists. The pilot's knowledge of place and his skill of flying the helicopter are acquired through a long experience of flights. Each flight has its own characteristics, challenges and stories because weather, for example, always changes. Each flight is a learning experience and poses new challenges. The pilot, so to say, knows as he flies, as he journeys through the world along the path of travel. He knows as he moves along. His knowledge comes from stories and histories accumulated from journeys actually made. Ingold calls this kind of knowledge "inhabitant knowledge" or "knowledge of a wayfarer;" it is produced through "along integration," an integration made along the movement. He sums up the contrast between inhabitant knowledge and occupant knowledge by saying: "Thus instead of the complementarity of a vertically integrated science of nature and a laterally integrated geography of location, wayfaring yields an alongly integrated, practical understanding of the life-world. Such knowledge is neither classified nor networked but meshworked." 27

Of the aforementioned two modes of knowledge production, Ingold maintains, it is in the scientists' mode that the logic of inversion is at work. ${ }^{28}$ The logic of inversion is exercised when an occurrence, which is always embedded with its surroundings, is uprooted from its contexts and treated as discrete, self-contained facts. This logic places inhabitant knowledge and science in a hierarchy and claims that science has a higher status. So, knowledge is bifurcated into inhabitant knowledge and science. The same logic goes further, associating inhabitant knowledge with place and science with space. Claiming that inhabitant knowledge is local whereas science

26 Tim Ingold, Being Alive, p. 154.

27 Tim Ingold, Being Alive, p. 154; italics original.

28 See Tim Ingold, Being Alive, p. 155. 
is universal, it calls the former "culture" and contrasts it with the latter. The result is the well-known modern bifurcation of knowledge into culture and science.

Ingold is in favour of understanding knowledge as a practice of wayfaring, one being represented by the pilot's knowledge. ${ }^{29}$ He is against distillation and compartmentalisation in the production of knowledge. Why does he take this stance? For one reason, distillation and compartmentalisation tend to destroy the very meaning and coherence of the meshwork. For another, they turn stories into merely repositories of classified information. Despite the prevalence of official science, however, he is optimistic about the viability of conceiving and practising scientific knowledge as a wayfaring because "scientists are people too," he says, "and inhabit the same world as the rest of us." ${ }^{30}$

\section{INGOLD'S WAYFARING: REVIVING THE IMPOSSIBLE?}

In his exposition of wayfaring, Ingold shows a great favour for a premodern, animist, way of life and world-view. The proofs are abundant. ${ }^{31}$ To distinguish wayfaring from transport, for example, he adopts Wiebe's comparison between the native Inuit's understandings of travel over the land and sea ice and those of the sailors of the Royal Navy. On another occasion, he uses the travel of the Evenski people in Siberia in Anderson's field research as an example of habitation, which he contrasts with occupation. Moreover, he uses the writing of the Walbiri, Australian aboriginals, to make his point about life as tracks that can be traced out along the ground. He also uses early Medieval Christian monastic practices of perambulatory meditation and 'walking through the Scripture' as the examples of the dynamic relationship between the mental and the physical in wayfaring. ${ }^{32}$ Many more examples from other chapters of BA can be added to the list.

29 Tim Ingold, Being Alive, p. 155.

30 Tim Ingold, Being Alive, p. 155.

31 See Tim Ingold, Being Alive, pp. 149, 151.

32 Tim Ingold, Being Alive, p. 199. 
What message does the use of these examples convey? Many readers find it difficult to resist the impression that these pre-modern worldviews and ways of life are for Ingold the alternatives to the established view of life and science. Ingold's wayfaring appears to them to be calling for the revival of such worldviews and ways of life in our modern time. The critical-and even cynical-questions they raise are: Is the revival possible? Is Ingold not too nostalgic? Is he not overly optimistic? ${ }^{33}$

Pessimism about the possibility of the revival is easy to understand. Modern society is essentially capitalist and highly technological. The spirit of capitalism pervades all facets of the society and strongly influences individual mentality. It influences the way people perceive things and the way they live their lives. The capitalist quest for profit makes it difficult to live out the ways of life that Ingold's wayfaring envisions. Take travel from home to the workplace as an example. This kind of travel is undoubtedly the spatial movement that modern people do most often. The capitalist quest for profit (in the guise of discipline, effectiveness, efficiency, etc.) requires that the travel is done fast. Modern people move and are moved in the fast lane. Being mindful of happenings-which Ingold celebrates in his notion of wayfaring - in this rush is a luxury. In addition, technology makes it even more difficult to revive and live out the way of life and worldview that Ingold's wayfaring endorses. Technology offers life comfort and allurement that are difficult to resist. Leaving this comfort would be painful, physically and psychologically (with the most painful encounter probably being the encounter with uncertainty and the uncontrollable).

Surprisingly, however, Ingold maintains that he does not intend to call for a revival of the pre-modern way. Following is his statement aiming at clearing up the misunderstanding of his project:

33 These are among the questions that attendants raised when Ingold delivered the inaugural lecture titled "Anthropology and the Art of Inquiry" at the Faculty of Social Sciences of KU Leuven on September 24, 2013. An attendant even mockingly asked him as to what extent he is "primitive" and how far he would go for his "primitiveness" in this modern age. 
The accusation of nostalgia (p. 9) is one that I have often encountered. Am I really calling for the reinstatement of ways of being and living that have been overtaken by modernism? Not exactly. My argument through-out is that modernism blinds us, or prevents us from recognising, existen-tial truths - as though we were trapped in a hall of mirrors. It is not that these truths are no longer there. We are still wayfarers, I would contend, just as we have always been. But this wayfaring is buried under a stance of denial. ${ }^{34}$

With this remark, Ingold's work can thus be said to be an anthropological critique of modernity. Unfortunately, Ingold does not go further explaining what an alternative to this discontented modernity might be. However, taking the aforementioned remark plus Ingold's silence concerning the alternative, the safest thing to say may be that Ingold proposes what can be termed "wayfaring modern way," i.e., a modern way embodying a greater mindfulness of the dynamism and richness of life, of beingin-the-world.

How feasible is this version of modern way? I believe it is possible to live it out, though the chance for it to be the mainstream way of life and worldview is rather remote. Only few people can live it out. These are persons, usually idealistic, who have very strong wills to renounce the comforts and allures of the modern way. Just as Ingold's notion of wayfaring is a tiny stream in today's science, so the wayfaring modern way remains the view of the few in modern society. The structure and spirit of modern culture simply do not allow it to be the way of the mass. In this very situation, Ingold's wayfaring stands as a prophetic, critical voice in the desert of the official view of science and life. It provides an inspiration for the few who aspire to live out an alternative way of life. ${ }^{35}$ Or else, it serves as a reminder for the many of the importance of a mindfulness of the happenings when living in modern society. As history witnesses, a

34 Ingold makes this clarification in his email to the writer dated October 10, 2013.

35 Ingold's wayfaring can thus be said to be-to borrow Mannheim's term-a utopia. For Mannheim's definition of utopia, see Karl Mannheim, Ideology and Utopia: An Introduction to the Sociology of Knowledge, translated by Louis Wirth and Edward Shils, eighth impression (London: Routledge and Kegan Paul Ltd., 1966), p. 173. 
society always needs a prophetic voice and a critical reminder in order to remain healthy and balanced.

\section{SELF-IDENTITY AND CITIZENSHIP}

Ingold uses the notion of wayfaring to describe what he believes to be the characteristics of life and of human beings. Life is for him a process, a becoming, open ended, always on the move. ${ }^{36}$ So is a human being. "The wayfarer is continually on the move," he writes, "[m]ore strictly, he is his movement." ${ }^{37}$ This passage, to my understanding, means not only that movement is a characteristic of a human person but also that one's movement makes what one is (one's character is created by one's movement along the pathway). This view of life and human beings raises some serious implications with regard to self-identity and citizenship, the issues which political philosophy has been increasingly preoccupied with since the publication of Michael Sandel's Liberalism and the Limits of Justice (1982). Is there self-identity at all in Ingold's notion of wayfaring? What kind of self-identity, if any, does this notion envision? What kind of citizens does such self-identity envisage?

The standard view of self-identity maintains that despite the flow of change in one's life, there are some elements that remain the same in one's self. Some degree of constancy, so to say, is at work. ${ }^{38}$ These unchanging elements constitute the self-identity of a person. For example, when Guru Dusu introduces himself in the Lamaholot language saying "Go ata Leworahang" ("I am an inhabitant of Leworahang"), he regards the village of Leworahang as part of his identity. This is possible only if there is a long close attachment between him and the village, be it because of his being born in Leworahang or his being an inhabitant of Leworahang for a long time. Another example: when Cynthia says "Mrs. Elisabeth is a generous lady," this means that being generous is an aspect of Mrs.

36 Tim Ingold, Being Alive, pp. 69, 150, 152.

37 Tim Ingold, Being Alive, p. 150.

38 Ferdinand Santos \& Santiago Sia, Personal Identity, the Self, and Ethics (Houndmills: Palgrave Macmillan, 2007), p. 3. 
Elisabeth's identity. Attaching this quality to Mrs. Elisabeth's personality can make sense only if she has practised generous acts frequently and constantly for a long time.

From the viewpoint of this mainstream view, it seems that there is no place for self-identity in Ingold's wayfaring. This is because in a continuous movement, there is no time for elements of experience to solidify so as to form self-identity. There is no chance for a close attachment to grow. Or, if there is self-identity at all in this notion (i.e., when someone says, for example, " 'always on the move' is my identity"), it is not a substantive one. It is just a play of words.

But is it true that Ingold's wayfaring produces a person without selfidentity? I argue that it is not. Note that Ingold distinguishes two kinds of people: occupants and inhabitants. ${ }^{39}$ He makes it very clear that his notion of wayfaring views persons as inhabitants. What are the characteristics of an inhabitant? To summarise Ingold's own description, an inhabitant is someone who actively engages himself with the country that opens up along his path, who knows the region as an insider through experiencing the dynamism of the region by himself, and who binds his lines and stories with those of others in the region so as to constitute a meshwork. ${ }^{40}$ In these characteristics, especially in the idea of meshwork, one can sense the subtle presence of constancy and attachment in the inhabitant's self. So, Ingold's wayfarer does have self-identity. It is only that the kind of self-identity that Ingold's notion of wayfaring projects is rather different from that of the mainstream. It is a dynamic self-identity, not a static one.

Now let us push our enterprise further to the political realm. If we are to read Ingold's notion of wayfaring with the eyes of a political philosopher, what would be the new insights that may come out from it? The immediate one that comes to my mind is the kind of citizens and citizenship that this notion envisions. Here again, Ingold's distinction between

39 Tim Ingold, Being Alive, pp. 151, 153.

40 Tim Ingold, Being Alive, pp. 150, 152, 153. 
occupants and inhabitants is instructive and relevant. These two kinds of travellers represent two different kinds of citizens.

Note that Ingold associates occupants with the idea of place-bound life and network. ${ }^{41}$ Place-bound life is a life that is confined to a space only; it is a life lived in this place or that place. ${ }^{42}$ Network signifies a line of connection with place and other people that is spread across the surface; it is, so to say, a shallow connection. Citizens as occupants are thus deeply bound to their country to the extent that they confine themselves to their own country (the element of place-bound life) while limiting themselves to a shallow relationship when engaging with people of other countries (element of network). ${ }^{43}$ The combination of all these characters and attitudes can easily lead to strong nationalism and even chauvinism, which—as the two World Wars witness to us-are calamitous.

The idea of citizens as inhabitants presents us with a different picture. Inhabitants, in Ingold's view, have certain traits. ${ }^{44}$ First of all, they view and regard their lives as habitation. They know the place and see themselves as integral parts of it; they are people of the land. Besides, their relationship with others is a meshwork. This means that they bind their lines, stories and lives with others in a close-knitted way. Nonetheless, they do not confine themselves to the(-ir) place. This is because they regard and experience their existence as place-binding, i.e., as lineal movement along the paths. They regard both their very selves and their lives as open ended. Their meshworks also have open ends, signalling openness towards others and showing a willingness to expand the relationship. Citizens as inhabitants thus have a strong fellow-feeling or civic tie, love their country, but at the same time go beyond their own country so as to

41 Tim Ingold, Being Alive, pp. 148, 151.

42 Tim Ingold, Being Alive, p. 147.

43 The writer does not rule out the possibility of the citizens as occupants engaging with their fellow citizens in a shallow civic relationship. This can happen as it is in the case of a country heavily divided by ethnicity and culture. However, it is an exception rather than a rule. What is usually the case is that citizens of this kind are tied by a strong fellow-feeling.

44 See Tim Ingold, Being Alive, p. 151 
reach people of other countries in their joy and sufferings. In short, they are good citizens of their country but also good citizens of the world. This, to my reading, is the kind of citizens and citizenship that Ingold's wayfaring implies. For this reason, I find this notion appealing.

\section{DOING PHILOSOPHY AS A WAYFARING}

Ingold uses his notion of wayfaring as a critique of what he calls "official science," i.e., the mainstream scientific understanding and practice of today. He blames it for the logic of inversion, the logic which has led to the primacy of the abstract over the concrete and life over the properties of life in anthropology. He accuses mainstream science as the culprit of distillation and compartmentalisa-tion in the production of knowledge. So, Ingold's chief target of criticism is official science.

This does not mean, however, that philosophy can escape his criticism. In fact, Ingold also levels some severe critiques against philosophy. It is not difficult to find such critiques. First, in Chapter 12 of BA, he blames philosophers of place for the widespread belief that human beings can only live and know in places, for the classification of place into lower and higher levels, and for the knowledge of the place through armchair approach. ${ }^{45}$ Second, he equalises the works of anthropologists which deal more with materiality than materials with "the abstract rumination of philosophers and theorists". ${ }^{46}$ This approach, in his view, is something to be lamented of. Third, he also traces the traits of mainstream sciencewhich he disfavours - to Immanuel Kant and the hylomorphic model of making to Aristotle. ${ }^{47}$ Fourth, he asserts that the abstract rumination and armchair method that anthropologists adopt from philosophy isolate and

45 Against the armchair approach of philosophers to place, he, for instance, writes: “Only a philosopher could look from his sitting room and see the whole house! For its ordinary residents, the house or apartment is disclosed processionally, as a temporal series of vistas, occlusions and transitions unfolding along the myriad of pathways they take, from room to room and in and out of doors, as they go about their daily tasks." Tim Ingold, Being Alive, p. 146.

46 Tim Ingold, Being Alive, p. 20.

47 Tim Ingold, Being Alive, pp. 111, 210. 
marginalise anthropologists in public discussion of the great questions of social life. ${ }^{48}$ Accusing philosophy as the culprit, he calls for the liberation of anthropology from philosophers and their armchair method:

With its dreams of generalisation shattered, where should anthropology go? [....] Should it abandon its project for the work of philosophers who have never mustered the energy or conviction to leave their armchairs? I have argued for a discipline that would return to these questions, not in the armchair but in the world. We can be our own philosophers, but we can do it better thanks to its embedding in our observational engagements with the world and in our collaborations and correspondences with its inhabitants. What, then, should we call this lively philosophy of ours? Why, anthropology, of course. ${ }^{49}$

This, undoubtedly, is the most overt accusation and the fiercest critique against philosophy.

How sound is this accusation? How tenable is this critique? To respond to this critique and accusation, three points can be made. First of all, it seems to me that Ingold does not mean to make a blanket statement about philosophy. To my reading, what he targets in his critique, is rather specific: certain philosophers and certain mode of doing philosophy. He targets this philosopher or that, this way of doing philosophy or that. He, so to say, does not shoot rampantly at the philosophy camp. But in case that my reading is not correct and that Ingold really means to direct the accusation to the whole camp of philosophy, then it can convincingly be said that Ingold does contradict himself. His own work witnesses this contradiction. When elaborating his notion of wayfaring, he adopts the thoughts of José Ortega y Gasset, Maurice Merleau-Ponty, Alfred North Whitehead, Henri Bergson and Martin Heidegger. ${ }^{50} \mathrm{He}$ develops his own thoughts out of the ideas of these thinkers. Who are these people? They are, undoubtedly, philosophers. Furthermore, Ingold's approach and some

48 Tim Ingold, Being Alive, p. 143.

49 Tim Ingold, Being Alive, p. 243.

50 Tim Ingold, Being Alive, pp. 7, 12, 13, 147. 
of his ideas are not new to a mode of doing philosophy called "phenomenology." His statement that locomotion and cognition are inseparable, ${ }^{51}$ for instance, was already anticipated by Edmund Husserl almost a century ago in his Analyses Concerning Passive and Active Synthesis: Lectures on Transcendental Logic. ${ }^{52}$ This all renders Ingold's critique untenable or only partially tenable at best, if such critique is meant to apply to philosophy as a whole.

The second point concerns what Ingold calls "the abstract rumination of philosophers." This is in fact an old critique put in a new banner. Philosophy has been lambasted for its abstract enterprise not only by those outside this discipline but also by the insiders. ${ }^{53}$ This critique has merits in the sense that it does reflect the reality of philosophy. It is true that philosophy works and deals primarily with ideas and not so much with materials. Nevertheless, it should be noted that there are many branches or sub-fields of philosophy, which differ from one another in terms of abstractness. Sub-fields of theoretical philosophy such as metaphysics and epistemology, for instance, engage in a highly abstract enterprise. This simply cannot be avoided due to the nature of the subfields themselves. But the sub-fields that fall into the category of practical philosophy are rather different. Political philosophy and applied ethics, for example, take into account the reality of life of people provided by sociologists, anthropologists, economists and political scientists in order to be able to come up with sound and viable proposals. ${ }^{54}$ Here in these

51 Tim Ingold, Being Alive, p. 17.

52 Edmund Husserl, Analyses Concerning Passive and Active Synthesis: Lectures on Transcendental Logic, translated by A.J. Steinbock (Dordrecht: Kluwer Academic Publishers, 2001), pp. 39-46.

53 An example of the critique from an insider is one put forward by Bernard Williams in his Ethics and the Limits of Philosophy (London: Routledge, 2006). Williams calls the pattern of abstract and distantiated thinking in philosophy "Archimedean point." This pattern of philosophical venture, he maintains, is rooted in the philosophies of Aristotle and Kant (see p. 33).

54 An example that the writer can give is Ethics and Public Policy seminar that he attended during the 2012-2013 academic year. This one-year seminar was jointly organised by KU Leuven and UC Louvain and took "Social Justice in the European Union: Principles, Institutions, Policies" as its theme. Philosopher Philippe Van Parijs' work and the 
sub-fields, doing philosophy is not a totally abstract enterprise. It is rather a down-to-earth engagement.

However, this down-to-earth enterprise is not exactly the same as what Ingold has in mind. This brings me to the third point, the one concerning Ingold's critique of 'armchairs' or being-in-the-armchair in philosophy. By 'being-in-the-armchair' Ingold means a scholarly method which "cocoon[s] the scholar in a sedentary confinement that insulates him almost completely from any kind of sensory contact with his surroundings." ${ }^{55}$ He contrasts this approach with "being-in-the world," i.e., an approach in which a scholar works and studies with people. Here, a scholar inhabits the field with the people and meshes with them. His knowledge comes out of these interactions. This is not only a matter of taking the reality in the field and the concrete situation seriously. It is rather living with people, discussing with them in face-to-face conversation and letting one's thinking be shaped by the interactions. ${ }^{56}$

I find this critique very radical and difficult to refute as it strikes at the heart of philosophy, i.e., to its method. Rational critical reflection (of reality in its totality) is known to be the method of philosophy. ${ }^{57}$ It has been long held that the use of this method makes an enterprise a philosophical enterprise. Employing Ingoldian method of being-in-the-world

exchange of ideas between him and economist Frank Vandenbroucke in the seminar sessions show how sociological, political and economic information (of each EU member-state) is taken seriously when doing philosophy.

55 Tim Ingold, Being Alive, p. 238.

56 In his email of October 10, 2013, Ingold re-stated what he thinks to be the main difference between anthropology and philosophy and reveals his position with regard to philosophy: "The question of where I stand in relation to philosophy is more difficult. I have a very ambivalent relation to the subject. I do think of anthropology as a kind of philosophy, but it is a 'philosophy with the people in'. The implied criticism is that mainstream philosophy leaves the people out. This doesn't mean that it is not about people. The point is rather that it is not with people. It seems that the temptation, with philosophers, is always to appeal to what they call the 'canon', comprising the assembled masterworks of the past. They draw on the canon to say things about people's lives. Anthropology - at least my kind of anthropology - goes the other way about. It draws on what it can learn from other people's lives, and indeed from the world in general, to say things (often critical things) about the canon".

57 Stephen Palmquist, The Tree of Philosophy (Hongkong: Philopsychy Press, 2000), p. 29. 
in doing philosophy would thus lead to the loss of identity of philosophy and to the dissolution of philosophy into empirical science, which is but another name for the death of philosophy. ${ }^{58}$

Despite the possible destruction it brings about, Ingold's wayfaring in fact carries an inspiration. The notion opens up a possibility of doing philosophy in an unusual way, in a way that is different from the mainstream practice in philosophy. It is "doing philosophy as wayfaring." This way of doing philosophy retains the existing method of philosophy while embracing Ingold's being-in-the-world method. The writer proposes it as an alternative way of doing philosophy and the same time as a response to Ingold's critique of philosophical armchair.

The basic idea of doing philosophy as wayfaring is that one philosophises by using rational critical reflection while living, meshing and interacting with people in the field, in their ebbs and flows of life. It is a way of philosophising as an inhabitant. This way of doing philosophy is in fact not new at all. Socrates, as Plato informs us in the Republic, did it as he was walking in Athens and discussing various issues with the Athenians. ${ }^{59}$

Some pessimism nonetheless may strike. Given that the structure of society nowadays is rather different from the structure of society in Socrates' time, is this proposal feasible? It is. In fact, some individuals in the third-world countries are practising such a way of doing philosophy. They are people who study philosophy as part of their training and engage in the socio-political empowerment at the grass-roots in villages. They live with the villagers, interact with them in their daily lives and discuss with them about different socio-political problems, including poverty, juvenile delinquency, and environmental problems caused by logging and

58 "Being-in-the-world" is also a philosophical notion; it is Heidegger who introduces it. Ingold in fact adopts his notion from Heidegger (Tim Ingold, Being Alive, p. 147). However, seen from the point of view of Ingold's anthropological being-in-the-world, Heidegger's being-in-the-world still carries the flavour of armchair.

59 Plato, "Republic," in Plato Complete Works, edited by J.M. Cooper (Cambridge: Hackett Publishing Company, 1997), pp. 971-1223. 
mining. ${ }^{60}$ The interactions and discussion enrich both parties: the stories of the villagers open the eyes of the philosophers to see the richness of the wisdom of the indigenous while the stories of the philosophers open the eyes of the grass-roots to realise their political rights as citizens. The interaction turns out to be a two-way empowerment. Together they then make a plan for action and execute it so as to bring the village and the larger society to a better condition.

By advancing this story of doing philosophy, I do not mean that all philosophers have to do philosophy in that way. One context wherein a philosopher lives and philosophises differs from another. Furthermore, not all sub-fields of philosophy offer a possibility of doing philosophy with the people. I am fully aware that these differences make it impossible for all philosophers to do philosophy in the way I described above. My point is rather that doing philosophy as wayfaring is not an impossible enterprise, though — and this should be noted-it never goes without risks. ${ }^{61}$

60 One example that comes to my mind is the experiences of some of the alumni of the Major Seminary of St. Paul, Ledalero, one of the constituents of the Catholic Institute of Philosophy and Theology (STFK) Ledalero, Indonesia. Ledalero incorporated justice, peace, democracy and the integrity of creation into its formation some years ago as a response to the pressing needs for a more democratic and just Indonesian society. What the institute has been doing as part of its commitment for social justice and democracy is to equip its students with philosophy, theology, critical thinking and skills for social analysis, and to send its students to live in remote villages with the grass-roots on a regular basis. The efforts have seen a positive result. After completing their academic formation, some of the alumni engage in the grass-root empowerment as inter alia NGO activists, school teachers, and parish priests. They live with people mostly in rural areas, interact with them in their daily lives, discuss with them about many things in life, make plans for action with them, and execute the plans together. The writer takes this grass-root empowerment as an example of doing-philosophyas-a-wayfaring for two reasons: first, because it is philosophical (and theological) knowledge and skills that they exercise in the empowerment and, second, because they do it with the people and not from armchairs.

61 One of the risks that Ulrich Melle brings to my attention is the rigour of the enterprise, which has been long viewed as one of the characteristics of philosophy proper. My proposal of doing philosophy as a wayfaring, he warns, would run the risk of sacrificing the rigour of the discipline. This would in turn lower the quality of philo-sophy proper. I agree that doing-philosophy-as-a-wayfaring with the grass-roots would indeed lead to a kind of philosophy which is not as rigorous as the one in the academia. This, in my opinion, is nevertheless a risk worth taking if we are to treat philosophy as an emancipatory discipline in a context that requires us to treat it that way. 


\section{CONCLUDING REMARKS}

In this article the writer has attempted to make sense of Ingold's wayfaring and to explore the challenges, implications and inspirations of this notion for the thinking of some issues related mostly to political philosophy. As the writer comes to the end of this undertaking, he finds it impossible to make black-or-white statements about Ingold's wayfaring. It is as difficult to discard this notion altogether as to wholly agree with it.

This is probably because Ingold uses the main terms, such as "wayfaring," "movement" and "meshwork" equivocally rather than univocally. To each term he assigns not only a literal meaning but also a metaphorical one. However, this equivocality should not be lamented of. The elasticity of these terms provides an ample space for manoeuvring into different directions of thought. The manoeuvre into the issues of citizens and citizenship attempted in this article, for instance, is possible thanks to the figurative meanings of occupants and inhabitants.

Finally, given the character of Ingold's notion of wayfaring, it may be best to regard this article as somewhat of a wayfaring. As the writer does a wayfaring into Ingold's wayfaring of mind, Ingold's stories and the writer's stories entwine and make a meshwork, a binding together of lines or stories that are enriching and open-ended. The writer hopes that the readers will come with their own stories and expand this meshwork as they read this piece of work.

\section{REFERENCES}

Hornby, Albert S. Oxford Advanced Learner's Dictionary. Oxford: Oxford University Press, 2010.

Husserl, Edmund. Analyses Concerning Passive and Active Synthesis: Lectures on Transcendental Logic. Translated by A.J. Steinbock. Dordrecht: Kluwer Academic Publishers, 2001.

Ingold, Tim. Being Alive: Essays on Movement, Knowledge and Description. London: Routledge, 2011.

Mannheim, Karl. Ideology and Utopia: An Introduction to the Sociology of Knowledge. Translated by Louis Wirth and Edward Shils. London: Routledge and Kegan Paul Ltd., 1966. 
Nouwen, Henri J.M. The Return of the Prodigal Son: A Story of Homecoming. New York: Doubleday, 1994.

Palmquist, Stephen. The Tree of Philosophy. Hongkong: Philopsychy Press, 2000.

Plato. "Republic." In Plato Complete Works, ed. J.M. Cooper. Cambridge: Hackett Publishing Company, 1997, pp. 971-1223.

Santos, Ferdinand and Santiago Sia. Personal Identity, the Self, and Ethics. Houndmills: Palgrave Macmillan, 2007.

Williams, Bernard. Ethics and the Limits of Philosophy. London: Routledge, 2006. 